\title{
EVALUATION OF LEAD TOLERANT PLANT GROWTH PROMOTING RHIZOBACTERIA FOR PLANT GROWTH AND PHYTOREMEDIATION IN LEAD CONTAMINATION
}

Evaluación del efecto de rizobacterias promotoras del crecimiento tolerantes al plomo en el crecimiento vegetal y la fitorremediación en contaminación por plomo

Muhammad SALEEM ${ }^{1 *}$, Hafiz Naeem ASGHAR ${ }^{1}$, Zahir Ahmad ZAHIR ${ }^{1}$ and Muhammad SHAHID ${ }^{2}$

${ }^{1}$ Institute of Soil and Environmental Sciences, University of Agriculture. Faisalabad-38040, Pakistan

${ }^{2}$ Department of Chemistry and Biochemistry, University of Agriculture, Faisalabad-38040, Pakistan

*Corresponding author: msaleemises@gmail.com

(Received: October 2017; accepted: November 2017)

Key words: contamination, heavy metals, plant growth promoting rhizobacteria, plant physiology, sunflower

\begin{abstract}
The present study was conducted to evaluate five pre-characterized lead tolerant plant growth promoting rhizobacteria: Pseudomonas gessardii strain BLP141 (S2), Pseudomonas fluorescens A50 (S5), Pseudomonas syringae pv. syringae B728a (S6), Pseudomonas stutzeri strain 28a24 (S8) and Pseudomonas fluorescens strain LMG 2189 (S10), for their plant growth promotion, phytoremediation potential and physiological response on Helianthus annuus L. as test crop, exposed to different lead concentrations $(300,600$ and $900 \mathrm{mg} / \mathrm{kg}$ ). Crop was harvested after 30 days of sowing and data regarding growth parameters (root shoot length, root shoot fresh and dry weights), physiological attributes (photosynthetic rate, transpiration rate and substomatal $\mathrm{CO}_{2}$ ), and lead content in root and shoot of sunflower, were recorded. Results revealed that lead contamination decreased the growth and physiological attributes of plants at all levels of lead stress; however inoculation with lead tolerant rhizobacteria reversed the toxic effect of lead on the plants and improved the growth and physiological attributes of sunflower in lead contamination, as compared to plants grown in the un-inoculated lead contaminated treatments. Among the five isolates, S2, S5 and S10 promoted more growth, improving the physiological attributes and phytoremediation potential of plants at all levels of contamination as compared to plants grown in lead stress without inoculation.
\end{abstract}

Palabras clave: contaminación, metales pesados, rizobacterias promotoras del crecimiento, fisiología vegetal, girasol

\section{RESUMEN}

Se evaluaron cinco rizobacterias promotoras del crecimiento tolerantes al plomo precaracterizadas: Pseudomonas gessardii cepa BLP141 (S2), Pseudomonas fluorescens A50 (S5), Pseudomonas syringae pv. syringae B728a (S6), Pseudomonas stutzeri cepa 28a24 (S8) y Pseudomonas fluorescens cepa LMG 2189 (S10), con relación a su efecto en el crecimiento, potencial de fitorremediación y respuesta fisiológica en Helianthus annuus L. como cultivo de ensayo expuesto a diferentes concentraciones de plomo $(300,600 \mathrm{y}$ $900 \mathrm{mg} / \mathrm{kg}$ ). El cultivo se cosechó después de 30 días de sembrado y se registraron los 
datos referentes a parámetros de crecmiento (longitud del brote y la raíz, peso fresco y seco del brote y la raíz), atributos fisiológicos (tasa fotosintética y de transpiración, $\mathrm{CO}_{2}$ estomático) y contenido de plomo en raíces y brotes de girasol. Los resultados indican que la contaminación por plomo mermó tanto el desarrollo como los atributos fisiológicos de las plantas en todos los niveles de agresión por plomo; sin embargo, la inoculación con rizobacterias tolerantes al plomo revirtió los efectos tóxicos y mejoró tanto el crecimiento como los atributos fisiológicos del girasol contaminado por este metal, en comparación con plantas cultivadas sin este tratamiento. De las cinco cepas aisladas, S2, S5 y S10 promovieron mayor crecimiento y mejoraron en mayor medida los atributos fisiológicos y el potencial de fitorremediación de las plantas en todos los niveles de contaminación en comparación de plantas cultivadas en un ambiente de agresión por plomo sin inoculación.

\section{INTRODUCTION}

Lead $(\mathrm{Pb})$ is one of the toxic heavy metals that have negative impacts on soil diversity, growth of plant and health of human beings through entering the food chain. Soils are the ultimately reserves for lead and serve as one of the chief possibilities for human exposure to this metal (Mangkoedihardjo and Surahmaida 2008). In Pakistan, due attention has not been given to the control and management of industrial wastes and other pollutants (Faryal et al. 2007). Water and soil polluted with heavy metals cause main environmental and human health issues that are still lacking affordable and effective technical solutions. Remediation techniques could be physical, chemical and biological approaches (Dermont et al. 2010). As compared to physical and chemical techniques, phytoremediation is a successful technique for the remediation of soils and water polluted with metals (Terry and Bañuelos 2000, Hadi and Bano 2009), with no side effects, more aesthetic benefits and more time-effective technology (Jadia and Fulekar 2009). It has been reported that sunflower is an efficient hyper-accumulator of heavy metals, especially lead and cadmium from soils. Due to more biomass production, fast growing, more canopy and taproot system, sunflower has the ability to remediate metal polluted soils (Sewalem et al. 2014). However, when ions of heavy metals are present in the environment in quantities that exceed the permissible limits, they are taken up by plant roots and reach the shoots, damaging metabolic processes and causing a reduction in growth (Bingham et al. 1986, Mourato et al. 2015). Most of the hyper-accumulators are not suitable for phytoremediation due to their slow growth and low biomass production in contaminated soils (Cheng 2003, Chibuike and Obiora 2014). The use of phytoremediation alone is time consuming, and success with this technique depends upon accumulation of heavy metals, tolerance to them and biomass formation capacity of plants in a metal stress environment (Grčman et al. 2001, Chibuike and Obiora 2014). This problem could be solved by using phytoremediation associated with a metal-tolerant plant growth promoting rhizobacteria (PGPR) (Ma et al. 2011). Recently, microbe-assisted phytoremediation has emerged as a more successful approach for remediation of metal polluted soils (Koo and Kyung-Suk 2009), since PGPR have the capacity to enhance the growth of host plants through various mechanisms involving the production of specific compounds and increasing nutrient uptake. Several established studies also indicate that PGPR can reduce the toxicity of heavy metals and promote the growth of plants under stress by Ni, Pb or Zn (Jing et al. 2007). Furthermore, some rhizobacteria can excrete organic acids to enhance the bioavailability of heavy metals and certain varieties of bacteria (mainly PGPR) have been reported as phytoextraction assistants, such as Pseudomonas spp., Bacillus spp., Mesorhizobium sp., Microbacterium spp., Rhizobium spp., Variovorax sp., Rhodococcus sp., Psychrobacter spp., Flabobacterium sp., Sinorhizobium sp. and Achromobacter sp. (Koo and Kyung-Suk 2009). Metal-tolerant bacteria could endure metal stress via different mechanisms like exclusion of metal ions from the cell, intracellular metal ions accumulation and/or sequestration, metals biotransformation to less toxic forms and adsorption/desorption of metals (Mamaril et al. 1997). Mechanisms involved in transfer and mobilization of heavy metals by the rhizosphere microbes include acid and siderophore production, as well as phosphate solubilization (Khan et al. 2009). These metal-tolerant bacteria could enhance phytoremediation through the production of plant growth regulators like auxins, gibberellins and cytokinins (Bottini et al. 2004, 
Egamberdiyeva 2007), and can produce a similar effect as exogenously applied growth regulators (Hadi et al. 2010). They may also facilitate the growth of plants by reducing the ethylene-mediated stress by synthesizing ACC deaminase (Belimov et al. 2001). The mechanisms used by Pseudomonas sp. to improve the phytoremediation process include the improvement of the biomass production, the release of phytohormones, and the production of siderophore and low molecular weight organic acids. The latter increase the bioavailability and mobility of metals in soil and the accumulation in aerial plant parts (Chen et al. 2014).

The aim of this study was to evaluate the potential effect of selected lead tolerant PGPR on the growth and physiology of Helianthus annuus L. as a test crop, to elucidate their phytoremediation potential in the presence of lead stress.

\section{MATERIALS AND METHODS}

Five pre-characterized lead tolerant PGPR, Pseudomonas gessardii strain BLP141 (S2), Pseudomonas fluorescens A50 (S5), Pseudomonas syringae pv. syringae B728a (S6), Pseudomonas stutzeri strain 28a24 (S8), and Pseudomonas fluorescens strain LMG 2189 (S10) were selected to analyze their potential on plant growth promoting and phytoremediation. Jars/small pots ( $400 \mathrm{~mL})$ were employed for cultivation of sunflower plants., filled with sterilized sand and contaminated with lead chloride salt at three concentrations: 300, 600 and $900 \mathrm{mg} / \mathrm{kg}$. Inoculum was prepared by growing the selected strains in 250 $\mathrm{mL}$ conical flask with $100 \mathrm{~mL}$ of LB broth incubated at $28 \pm 2{ }^{\circ} \mathrm{C}$ in an orbital shaking incubator at $100 \mathrm{rpm}$ for three days. To attain uniform cell density $\left(10^{8}\right.$ $10^{9} \mathrm{CFU} / \mathrm{mL}$ ), an optical density of 0.5 , recorded at a wavelength of $535 \mathrm{~nm}$, was obtained by dilution. Surface sterilization of sunflower seeds was done by momentarily dipping in ethanol (95\%) and for $3 \mathrm{~min}$ in $\mathrm{HgCl}_{2}$ solution $(0.2 \%)$; subsequently six rinses with sterilized water were carried out. By using lead chloride salt, three levels $(300,600$ and $900 \mathrm{mg} / \mathrm{kg}$ of sand) of lead stress were developed. Sunflower seeds were dipped in the broth of the respective culture of isolates for inoculation for $5 \mathrm{~min}$. Then three inoculated sunflower seeds of each strain were kept in small pots contaminated with different levels of lead and without lead, except for the control, where only LB broth without inoculum dipped seeds was placed. Experiments consisted of 48 pots and after germination one plant per pot was maintained: 36 pots contained inoculated plants and 12 pots remained without inoculum. To meet the nutritional and water requirements of the seedlings, half strength Hoagland solution (Hoagland and Arnon 1950) was applied in the mall pots whenever needed. The pots were arranged according to a completely randomized design (CRD) with factorial arrangement and three repeats. Data regarding root/shoot length, fresh and dry weights, and lead contents in plants were determined after 30 days of sowing. Physiological attributes such as photosynthetic and transpiration rates, and substomatal $\mathrm{CO}_{2}$ were determined using a CIRUS-3 instrument before one day of harvesting. For lead determination, $50 \mathrm{mg}$ of grinded shoots and roots of sunflower samples were placed in conical flasks; a $10 \mathrm{~mL} \mathrm{HNO}_{3}: \mathrm{HClO}_{4}$ mixture in 3:1 ratio (on volume basis) was added to each flask and kept overnight. The next day, all flasks were heated on a hot plate and digested until the material became clear. Then the flasks were cooled and all materials were poured into $50 \mathrm{~mL}$ volumetric flasks; distilled water was added to each flask to increase volume up to 50 $\mathrm{mL}$ and contents filtered with filter paper. Lead was analyzed with an Atomic absorption spectrophotometer. Total biomass of plant was estimated by shoot dry weight plus root dry weight. For determination of lead removal, total dry weight of a plant was multiplied by its lead content. Lead removal efficiency (LRE) was determined by the following equation:

$\operatorname{LRE}(\%)=\frac{\mathrm{B} 1-\mathrm{B} 2}{\mathrm{~B} 2} \times 100$

where B1 is the lead uptake/removal by inoculated plants through and B2 the lead uptake/removal by uninoculated plants.

For the measurement of $\mathrm{Pb}$ in sand after harvesting, $2 \mathrm{~g}$ of air-dried sand were placed in $50 \mathrm{~mL}$ flasks and digested in a mixture of $\mathrm{HCl}, \mathrm{HNO}_{3}$ and $\mathrm{HClO}_{4}$. Residues were diluted with deionized water and analyzed with an atomic absorption spectrophotometer (Tuzen 2003).

The microbial population was determined by using the dilution plate technique with general purpose agar media (glucose peptone agar media). Media plates were inoculated with sand (obtained from the plants' rhizosphere) solution and incubated at $28 \pm$ $2{ }^{\circ} \mathrm{C}$ for $72 \mathrm{~h}$. Colony forming units (cfu/g of sand) from each sample were calculated through a colony counter. Two-way analysis of variance (ANOVA) was performed. Means were compared $(p<0.05)$ by applying Duncan's new multiple range test (DMRT) (Steel and Torrie 1984). Data were analyzed with statistical software (Statstix 8.1). 


\section{RESULTS}

Lead contamination reduced the shoot length up to 26,39 and $67 \%$ at 300,600 and $900 \mathrm{mg} / \mathrm{kg}$ lead stress, respectively, as compared to the control crop (which had neither inoculation nor heavy metal stress) (Table I). However, the shoot length was increased by inoculation with lead tolerant rhizobacterial isolates as compared to plants grown in metal stress without inoculation. Isolates S2 and S5 showed the most promising results, enhancing the shoot length up to 21 and $18 \%$, respectively, at 900 $\mathrm{mg} / \mathrm{kg}$ lead stress, as compared to plants grown at the same stress without inoculation.

It was observed that the shoot fresh and dry weights significantly $(p<0.05)$ decreased by lead stress as compared to plants grown in normal conditions without lead contamination and inoculation (control) (Table I). However, inoculation with lead tolerant rhizobacterial isolates reverted the toxic effect of lead on plants and improved the shoot fresh and dry weights in lead stress. It was noticed that among the isolates, more increment was shown by S2, which promoted increases of 31 and $44 \%$ at 900 $\mathrm{mg} / \mathrm{kg}$ in shoot fresh and dry weights, respectively, as compared to plants grown at the same stress without inoculation.

Root length was significantly $(\mathrm{p}<0.05)$ decreased by lead contamination as compared to control. Reduction in root length was up to 26,35 and $52 \%$ in lead contamination of 300,600 and $900 \mathrm{mg} / \mathrm{kg}$, respectively, as compared to plants grown in normal condi-

TABLE I. EFFECT OF LEAD TOLERANT PGPR ON SHOOT ATTRIBUTES (LENGTH, FRESH WEIGHT, AND DRY WEIGHT) OF SUNFLOWER PLANTS EXPOSED TO LEAD

\begin{tabular}{llllc}
\hline $\mathrm{Pb}(\mathrm{mg} / \mathrm{kg})$ & Treatment & SL $(\mathrm{cm})$ & SFW $(\mathrm{mg})$ & SDW $(\mathrm{mg})$ \\
\hline 0 & No inoculation & $20.86 \mathrm{~d}$ & $1980 \mathrm{c}$ & $850 \mathrm{e}$ \\
& S2 & $27.08 \mathrm{a}$ & $2760 \mathrm{a}$ & $1200 \mathrm{a}$ \\
& S5 & $26.65 \mathrm{ab}$ & $2560 \mathrm{ab}$ & $1116 \mathrm{c}$ \\
& S6 & $24.09 \mathrm{c}$ & $2380 \mathrm{~b}$ & $1038 \mathrm{~d}$ \\
& S8 & $25.53 \mathrm{bc}$ & $2700 \mathrm{ab}$ & $1174 \mathrm{~b}$ \\
& S10 & $26.60 \mathrm{ab}$ & $2700 \mathrm{ab}$ & $1177 \mathrm{~b}$ \\
\hline 300 & No inoculation & $16.59 \mathrm{hi}$ & $1490 \mathrm{~d}-\mathrm{i}$ & $620 \mathrm{j}$ \\
& S2 & $18.66 \mathrm{e}$ & $1700 \mathrm{~cd}$ & $743 \mathrm{f}$ \\
& S5 & $18.26 \mathrm{eg}$ & $1630 \mathrm{c}-\mathrm{f}$ & $710 \mathrm{~g}$ \\
& S6 & $17.5 \mathrm{e}-\mathrm{h}$ & $1570 \mathrm{~d}-\mathrm{g}$ & $680 \mathrm{~h}$ \\
& S8 & $18.06 \mathrm{ef}$ & $1640 \mathrm{c}-\mathrm{f}$ & $716 \mathrm{~g}$ \\
& S10 & $18.18 \mathrm{ef}$ & $1650 \mathrm{c}-\mathrm{e}$ & $721 \mathrm{~g}$ \\
\hline \multirow{2}{*}{600} & No inoculation & $15.00 \mathrm{jl}$ & $1280 \mathrm{e}-\mathrm{j}$ & $530 \mathrm{~m}$ \\
& S2 & $17.067 \mathrm{fi}$ & $1500 \mathrm{~d}-\mathrm{h}$ & $656 \mathrm{i}$ \\
& S5 & $16.66 \mathrm{gi}$ & $1430 \mathrm{~d}-\mathrm{i}$ & $623 \mathrm{j}$ \\
& S6 & $15.99 \mathrm{ik}$ & $1370 \mathrm{~d}-\mathrm{i}$ & $597 \mathrm{k}$ \\
& S8 & $16.46 \mathrm{hg}$ & $1440 \mathrm{~d}-\mathrm{i}$ & $630 \mathrm{j}$ \\
& S10 & $16.58 \mathrm{hi}$ & $1450 \mathrm{~d}-\mathrm{i}$ & $634 \mathrm{j}$ \\
\hline 900 & No inoculation & $12.47 \mathrm{~m}$ & $970 \mathrm{j}$ & $390 \mathrm{o}$ \\
& S2 & $15.06 \mathrm{jl}$ & $1270 \mathrm{f}-\mathrm{j}$ & 561 \\
& S5 & $14.66 \mathrm{kl}$ & $1180 \mathrm{~h}-\mathrm{j}$ & 5141 \\
& S6 & 13.991 & $1120 \mathrm{ij}$ & $489 \mathrm{n}$ \\
& S8 & $14.46 \mathrm{kl}$ & $1190 \mathrm{~h}-\mathrm{j}$ & $521 \mathrm{~m}$ \\
& S10 & $14.58 \mathrm{kl}$ & $1230 \mathrm{~g}-\mathrm{j}$ & $530 \mathrm{~m}$ \\
\hline
\end{tabular}

PGPR: plant growth promoting rhizobacteria, SL: shoot length, SFW: shoot fresh weight, SDW: shoot dry weight, S2: Pseudomonas gessardii strain BLP141 (), S5: Pseudomonas fluorescens A50, S6: Pseudomonas syringae pv. syringae B728a, S8: Pseudomonas stutzeri strain 28a24, S10: Pseudomonas fluorescens strain LMG 2189

Means sharing the same letters are statistically non-significant with the Duncan's new multiple range test at $\mathrm{p}<0.05$ 
tions with no contamination was applied (Table II). However, lead tolerant rhizobacterial isolates increased the root length at all levels of lead stress as compared to plants grown in lead stress without inoculation. Among the five isolates, S5 and S10 showed better results and promoted the root length up to 32 and $26 \%$ at $900 \mathrm{mg} / \mathrm{kg}$ lead contamination, respectively, as compared to plants grown at the same stress without inoculation.

A significant $(\mathrm{p}<0.05)$ reduction in root fresh and dry weight was recorded by the exposure of sunflower plants to lead stress. Root fresh and dry weights reduced up to 120 and $107 \%$ in lead contamination of $900 \mathrm{mg} / \mathrm{kg}$, respectively, as compared to control without metal stress and inoculation (Table II). Lead tolerant rhizobacterial isolates significantly $(\mathrm{p}<0.05)$ increased root fresh and dry weights at all levels of lead contamination as compared to plants grown in stress without inoculation. It was observed that among the five isolates, S10 remained at the top and improved the root fresh and dry weights up to 45 and $27 \%$, respectively, as compared to plants grown at same stress without inoculation.

Results showed that reduction in physiological attributes (photosynthetic rate, transpiration rate and substomatal $\mathrm{CO}_{2}$ ) was observed due to lead contamination (Table III). However, improvement in the physiological attributes of sunflower in lead contamination was observed by the application of lead tolerant bacteria as compared to plants grown in lead contamination without inoculation. Data showed that the maximum increment $(12 \%)$ in photosynthetic rate was shown by S10 at $900 \mathrm{mg} / \mathrm{kg}$ lead contamination, as compared to plants grown at the

TABLE II. EFFECT OF LEAD TOLERANT PGPR ON ROOT ATTRIBUTES (ROOT LENGTH, ROOT FRESH WEIGHT AND ROOT DRY WEIGHT) OF SUNFLOWER PLANTS EXPOSED TO LEAD

\begin{tabular}{lllll}
\hline $\mathrm{Pb}(\mathrm{mg} / \mathrm{kg})$ & Treatment & RL $(\mathrm{cm})$ & RFW (mg) & RDW (mg) \\
\hline 0 & No inoculation & $15.86 \mathrm{c}$ & $640 \mathrm{~d}$ & $310 \mathrm{~d}$ \\
& S2 & $20.53 \mathrm{ab}$ & $827 \mathrm{~b}$ & $420 \mathrm{ab}$ \\
& S5 & $22.083 \mathrm{a}$ & $872 \mathrm{a}$ & $400 \mathrm{bc}$ \\
& S6 & $19.09 \mathrm{~b}$ & $769 \mathrm{c}$ & $370 \mathrm{c}$ \\
& S8 & $21.603 \mathrm{a}$ & $870 \mathrm{a}$ & $420 \mathrm{ab}$ \\
& S10 & $21.657 \mathrm{a}$ & $889 \mathrm{a}$ & $430 \mathrm{a}$ \\
\hline 300 & No inoculation & $11.73 \mathrm{~d}-\mathrm{h}$ & $430 \mathrm{j}-1$ & $230 \mathrm{~g}-\mathrm{i}$ \\
& S2 & $13.06 \mathrm{de}$ & $526 \mathrm{ef}$ & $250 \mathrm{e}-\mathrm{g}$ \\
& S5 & $13.66 \mathrm{~d}$ & $380 \mathrm{mn}$ & $260 \mathrm{e}$ \\
& S6 & $12.59 \mathrm{df}$ & $507 \mathrm{fg}$ & $240 \mathrm{e}-\mathrm{h}$ \\
& S8 & $13.18 \mathrm{de}$ & $531 \mathrm{ef}$ & $250 \mathrm{ef}$ \\
& S10 & $13.26 \mathrm{de}$ & $534 \mathrm{ef}$ & $260 \mathrm{ef}$ \\
\hline \multirow{2}{*}{600} & No inoculation & $10.23 \mathrm{jk}$ & $550 \mathrm{e}$ & $190 \mathrm{kl}$ \\
& S2 & $11.46 \mathrm{e}-\mathrm{j}$ & $462 \mathrm{~h}-\mathrm{j}$ & $220 \mathrm{~h}-\mathrm{j}$ \\
& S5 & $12.06 \mathrm{~d}-\mathrm{g}$ & $470 \mathrm{hi}$ & $230 \mathrm{e}-\mathrm{i}$ \\
& S6 & $10.99 \mathrm{f}-\mathrm{k}$ & $443 \mathrm{i}-\mathrm{k}$ & $210 \mathrm{i}-\mathrm{k}$ \\
& S8 & $11.58 \mathrm{e}-\mathrm{i}$ & $466 \mathrm{hi}$ & $230 \mathrm{~g}-\mathrm{i}$ \\
& S10 & $11.66 \mathrm{~d}-\mathrm{h}$ & $486 \mathrm{gh}$ & $230 \mathrm{~g}-\mathrm{i}$ \\
\hline 900 & No inoculation & 7.691 & $290 \mathrm{o}$ & $150 \mathrm{~m}$ \\
& S2 & $9.467 \mathrm{kl}$ & $381 \mathrm{mn}$ & $190 \mathrm{kl}$ \\
& S5 & $10.17 \mathrm{jk}$ & $400 \mathrm{~lm}$ & $180 \mathrm{l}$ \\
& S6 & $8.993 \mathrm{l}$ & $360 \mathrm{n}$ & $170 \mathrm{l}$ \\
& S8 & $9.583 \mathrm{i}-1$ & $386 \mathrm{mn}$ & $180 \mathrm{kl}$ \\
& S10 & $9.74 \mathrm{~h}-\mathrm{k}$ & $420 \mathrm{kl}$ & $190 \mathrm{j}-1$ \\
\hline
\end{tabular}

PGPR: plant growth promoting rhizobacteria, RL: root length, RFW: root fresh weight, RDW: root dry weight, S2: Pseudomonas gessardii strain BLP141 (), S5: Pseudomonas fluorescens A 50, S6: Pseudomonas syringae pv. syringae B728a, S8: Pseudomonas stutzeri strain 28a24, S10: Pseudomonas fluorescens strain LMG 2189 Means sharing the same letters are statistically non-significant with the Duncan's new multiple range test at $\mathrm{p}<0.05$ 
same stress without inoculation. Maximum improvement in transpiration rate (9\%) was shown by S2 at $900 \mathrm{mg} / \mathrm{kg}$ lead stress, as compared to plants grown at the same stress without inoculation. Results show a $13 \%$ increment in substomatal $\mathrm{CO}_{2}$ stimulated by $\mathrm{S} 5$ at $900 \mathrm{mg} / \mathrm{kg}$ lead contamination as compared to plants grown at the same stress without inoculation.

Lead concentration in the root of inoculated sunflower plants in lead contamination significantly $(p<0.05)$ increased as compared to plants grown in lead stress without inoculation (Table IV). Isolates S10 and S2 showed maximum improvement in lead concentration in root of plants in lead stress and increased the lead content in root up to 18 and $17 \%$, respectively, at highest level of lead as compared to the same level of uninoculated lead treatment. Isolate S8 showed minimum increment in lead content in root and increased only $9 \%$ lead content in root at $900 \mathrm{mg} / \mathrm{kg}$ (of sand) lead stress as compared to plants grown in uninoculated same lead stress.

Inoculation with lead tolerant bacteria improved the lead concentration in shoot of sunflower plants at all levels of lead contamination as compared to plant grown in metal stress without inoculation (Table IV). Among the isolates, S5 and S10 improved maximum metal content in shoot up to 21 and $20 \%$, respectively, at highest level of lead as compared to same level of un-inoculated lead. Isolates S6 and S8 showed least effective performance and enhanced minimum metal content in shoot of sunflower in lead contamination as compared to plants grown in lead contamination without inoculation. Data (Table IV) also showed that maximum lead removal efficiency was observed by isolates $\mathrm{S} 10$ and $\mathrm{S} 5$ at $900 \mathrm{mg} / \mathrm{kg}$

TABLE III. EFFECT OF LEAD TOLERANT PGPR ON PHYSIOLOGICAL ATTRIBUTES (PHOTOSYNTHETIC RATE, TRANSPIRATION RATE AND SUBSTOMATAL $\mathrm{CO}_{2}$ ) OF SUNFLOWER PLANTS EXPOSED TO LEAD

\begin{tabular}{llccc}
\hline $\mathrm{Pb}\left(\mathrm{mg} \mathrm{kg}^{-1}\right)$ & Treatment & $\mathrm{A}(\mu \mathrm{mol} / \mathrm{m} / \mathrm{s})$ & $\mathrm{E}(\mathrm{mmol} / \mathrm{m} / \mathrm{s})$ & $\mathrm{Ci}(\mu \mathrm{mol} / \mathrm{mol})$ \\
\hline 0 & No inoculation & $13.30 \mathrm{~d}$ & $5.10 \mathrm{e}$ & $810 \mathrm{c}$ \\
& S2 & $13.48 \mathrm{c}$ & $5.70 \mathrm{a}$ & $837 \mathrm{~b}$ \\
& S5 & $13.98 \mathrm{ab}$ & $5.29 \mathrm{~d}$ & $880 \mathrm{a}$ \\
& S6 & $13.68 \mathrm{~b}$ & $5.33 \mathrm{~d}$ & $870 \mathrm{~b}$ \\
& S8 & $13.62 \mathrm{c}$ & $5.40 \mathrm{c}$ & $840 \mathrm{~b}$ \\
& S10 & $14.08 \mathrm{a}$ & $5.61 \mathrm{~b}$ & $865 \mathrm{a}$ \\
\hline 300 & No inoculation & $10.68 \mathrm{k}$ & $5.65 \mathrm{k}$ & $620 \mathrm{f}$ \\
& S2 & $11.08 \mathrm{hi}$ & $6.00 \mathrm{f}$ & $669 \mathrm{de}$ \\
& S5 & $11.68 \mathrm{f}$ & $5.95 \mathrm{~h}$ & $680 \mathrm{~d}$ \\
& S6 & $11.18 \mathrm{gh}$ & $5.89 \mathrm{~h}$ & $655 \mathrm{e}$ \\
& S8 & $11.28 \mathrm{~g}$ & $5.85 \mathrm{~h}$ & $651 \mathrm{e}$ \\
& S10 & $11.88 \mathrm{e}$ & $5.95 \mathrm{~g}$ & $660 \mathrm{e}$ \\
\hline & No inoculation & 9.681 & $5.45 \mathrm{l}$ & $540 \mathrm{j}$ \\
& S2 & $10.68 \mathrm{k}$ & $5.80 \mathrm{i}$ & $568 \mathrm{gh}$ \\
& S5 & $11.02 \mathrm{~h}-\mathrm{j}$ & $5.65 \mathrm{k}$ & $580 \mathrm{~g}$ \\
& S6 & $10.94 \mathrm{ij}$ & $5.67 \mathrm{k}$ & $555 \mathrm{~h}-\mathrm{j}$ \\
& S8 & $10.88 \mathrm{j}$ & $5.63 \mathrm{k}$ & $547 \mathrm{ij}$ \\
& S10 & $12.18 \mathrm{gh}$ & $5.75 \mathrm{j}$ & $560 \mathrm{hi}$ \\
\hline
\end{tabular}

PGPR: plant growth promoting rhizobacteria, A: photosynthetic rate, E: transpiration rate, CI: substomatal $\mathrm{CO}_{2}, \mathrm{~S} 2$ : Pseudomonas gessardii strain BLP141 (), S5: Pseudomonas fluorescens A50, S6: Pseudomonas syringae pv. syringae B728a, S8: Pseudomonas stutzeri strain 28a24, S10: Pseudomonas fluorescens strain LMG 2189

Means sharing the same letters are statistically non-significant with the Duncan's new multiple range test at $\mathrm{p}<0.05$ 
(of sand) lead stress as compared to other isolates at same lead concentration. Results regarding microbial population in rhizosphere and lead content (Table V) in sand after harvesting revealed that $\mathrm{S} 2, \mathrm{~S} 5$ and $\mathrm{S} 10$ isolates performed better in lead contamination as compared to control treatment without inoculation and other isolates in lead stress. Isolates S10 and S5 showed maximum lead removal capacity among the isolates in lead stress and treatments having lead stress without inoculation.

Figure 1 shows that lead contamination reduced the total biomass of plants as compared to plants grown in control without inoculation and contamination. However, application of lead tolerant bacteria reversed the toxic effect of lead on plants and enhanced total biomass of plants at all levels of lead contamination. Among all isolates, isolates S2, S5 and S10 showed most promising results at all levels of lead as compared to other isolates.

\section{DISCUSSION}

The present study was conducted to evaluate lead tolerant PGPR for plant growth promotion and phytoremediation potential exposed to lead stress by using sunflower as test crop. Our results showed a reduction in the growth and physiology of sunflower in lead contamination as compared to plants grown in uninoculated treatment without contamination.

TABLE IV. EFFECT OF LEAD TOLERANT PGPR ON THE PHYTOREMEDIATION POTENTIAL (LEAD IN ROOT AND SHOOT) OF SUNFLOWER PLANTS AND LEAD REMOVAL EFFICIENCY OF STRAINS

\begin{tabular}{|c|c|c|c|c|}
\hline \multirow{2}{*}{$\begin{array}{l}\mathrm{Pb} \\
(\mathrm{mg} / \mathrm{kg})\end{array}$} & \multirow[t]{2}{*}{ Treatment } & \multicolumn{2}{|c|}{$\mathrm{Pb}(\mathrm{mg} / \mathrm{kg})$} & \multirow{2}{*}{$\begin{array}{c}\text { Lead removal efficiency } \\
\text { of strains }(\%)\end{array}$} \\
\hline & & Root & Shoot & \\
\hline \multirow[t]{6}{*}{0} & No inoculation & ND & ND & ND \\
\hline & $\mathrm{S} 2$ & ND & ND & ND \\
\hline & S5 & ND & ND & ND \\
\hline & S6 & ND & ND & ND \\
\hline & $\mathrm{S} 8$ & ND & ND & ND \\
\hline & $\mathrm{S} 10$ & ND & ND & ND \\
\hline \multirow[t]{6}{*}{300} & No inoculation & 1461 & $104 \mathrm{k}$ & ND \\
\hline & $\mathrm{S} 2$ & $180 \mathrm{i}$ & $124 \mathrm{j}$ & 21.60 \\
\hline & S5 & $175 \mathrm{j}$ & $142 \mathrm{~g}$ & 26.80 \\
\hline & S6 & $172 \mathrm{j}$ & $129 \mathrm{ij}$ & 20.40 \\
\hline & $\mathrm{S} 8$ & $167 \mathrm{k}$ & 132 gi & 19.60 \\
\hline & $\mathrm{S} 10$ & $185 \mathrm{~h}$ & $137 \mathrm{gh}$ & 28.80 \\
\hline \multirow[t]{6}{*}{600} & No inoculation & $205 \mathrm{~g}$ & $162 \mathrm{f}$ & ND \\
\hline & $\mathrm{S} 2$ & $232 \mathrm{e}$ & $182 \mathrm{e}$ & 12.80 \\
\hline & S5 & $231 \mathrm{e}$ & $190 \mathrm{~d}$ & 14.70 \\
\hline & S6 & $224 \mathrm{f}$ & $181 \mathrm{e}$ & 10.35 \\
\hline & $\mathrm{S} 8$ & $225 \mathrm{f}$ & $188 \mathrm{~d}$ & 12.53 \\
\hline & $\mathrm{S} 10$ & $233 \mathrm{e}$ & $189 \mathrm{~d}$ & 14.98 \\
\hline \multirow[t]{6}{*}{900} & No inoculation & $304 \mathrm{~d}$ & $261 \mathrm{c}$ & ND \\
\hline & $\mathrm{S} 2$ & $358 \mathrm{a}$ & $287 \mathrm{~b}$ & 14.15 \\
\hline & S5 & $333 \mathrm{bc}$ & $317 \mathrm{a}$ & 15.04 \\
\hline & S6 & $335 \mathrm{~b}$ & $292 b$ & 10.97 \\
\hline & S8 & $330 \mathrm{c}$ & $290 \mathrm{~b}$ & 09.73 \\
\hline & $\mathrm{S} 10$ & $360 a$ & $315 \mathrm{a}$ & 19.46 \\
\hline
\end{tabular}

PGPR: plant growth promoting rhizobacteria, ND: non detectable, S2: Pseudomonas gessardii strain BLP141 (), S5: Pseudomonas fluorescens A50, S6: Pseudomonas syringae pv. syringae B728a, S8: Pseudomonas stutzeri strain 28a24, S10:

Pseudomonas fluorescens strain LMG 2189

Means sharing the same letters are statistically non-significant with the Duncan's new multiple range test at $\mathrm{p}<0.05$ 
TABLE V. MICROBIAL POPULATION IN RHIZOSPHERE, LEAD REMOVAL CAPACITY OF STRAINS AND LEAD IN SAND AFTER HARVESTING

\begin{tabular}{|c|c|c|c|c|}
\hline $\begin{array}{l}\mathrm{Pb} \\
(\mathrm{mg} / \mathrm{kg})\end{array}$ & Treatment & $\begin{array}{c}\mathrm{Pb} \text { in sand after } \\
\text { harvesting } \\
(\mathrm{mg} / \mathrm{kg})\end{array}$ & $\begin{array}{c}\mathrm{Pb} \text { removal } \\
\text { capacity }(\mathrm{mg} / \mathrm{kg})\end{array}$ & $\begin{array}{l}\text { Microbial population } \\
\text { in rhizosphere }(\mathrm{CFU} / \mathrm{g})\end{array}$ \\
\hline \multirow[t]{6}{*}{0} & No inoculation & ND & ND & Negligible \\
\hline & $\mathrm{S} 2$ & ND & ND & $3.45 \times 10^{5}$ \\
\hline & S5 & ND & ND & $4.12 \times 10^{5}$ \\
\hline & S6 & ND & ND & $2.30 \times 10^{5}$ \\
\hline & $\mathrm{S} 8$ & ND & ND & $3.60 \times 10^{5}$ \\
\hline & $\mathrm{S} 10$ & ND & ND & $4.12 \times 10^{5}$ \\
\hline \multirow[t]{6}{*}{300} & No inoculation & $109 \mathrm{~g}$ & $250 \mathrm{j}$ & Negligible \\
\hline & $\mathrm{S} 2$ & $55 \mathrm{hi}$ & $304 \mathrm{hi}$ & $3.33 \times 10^{5}$ \\
\hline & S5 & $42 \mathrm{ij}$ & 317 hi & $3.90 \times 10^{5}$ \\
\hline & S6 & $58 \mathrm{hi}$ & $301 \mathrm{i}$ & $3.23 \times 10^{5}$ \\
\hline & $\mathrm{S} 8$ & $60 \mathrm{~h}$ & $299 \mathrm{i}$ & $3.39 \times 10^{5}$ \\
\hline & $\mathrm{S} 10$ & $37 \mathrm{j}$ & $322 \mathrm{~h}$ & $3.67 \times 10^{5}$ \\
\hline \multirow[t]{6}{*}{600} & No inoculation & $292 \mathrm{~d}$ & $367 \mathrm{~g}$ & Negligible \\
\hline & $\mathrm{S} 2$ & $245 \mathrm{ef}$ & $414 \mathrm{f}$ & $3.45 \times 10^{5}$ \\
\hline & S5 & $238 \mathrm{ef}$ & $421 \mathrm{f}$ & $4.12 \times 10^{5}$ \\
\hline & S6 & $254 \mathrm{e}$ & $405 \mathrm{f}$ & $2.30 \times 10^{5}$ \\
\hline & S8 & $246 \mathrm{ef}$ & $413 \mathrm{f}$ & $3.60 \times 10^{5}$ \\
\hline & $\mathrm{S} 10$ & $237 \mathrm{f}$ & $422 \mathrm{f}$ & $4.70 \times 10^{5}$ \\
\hline \multirow[t]{6}{*}{900} & No inoculation & $394 \mathrm{a}$ & $565 \mathrm{e}$ & Negligible \\
\hline & $\mathrm{S} 2$ & $314 \mathrm{c}$ & $645 \mathrm{bc}$ & $4.50 \times 10^{5}$ \\
\hline & S5 & $309 \mathrm{c}$ & $650 \mathrm{~b}$ & $4.40 \times 10^{5}$ \\
\hline & S6 & $332 b$ & $627 \mathrm{~cd}$ & $4.36 \times 10^{5}$ \\
\hline & S8 & $339 \mathrm{~b}$ & $620 \mathrm{~d}$ & $2.13 \times 10^{5}$ \\
\hline & $\mathrm{S} 10$ & $284 \mathrm{~d}$ & $675 \mathrm{a}$ & $4.67 \times 10^{5}$ \\
\hline
\end{tabular}

PGPR: plant growth promoting rhizobacteria, ND: non detectable, S2: Pseudomonas gessardii strain BLP141 (), S5: Pseudomonas fluorescens A50, S6: Pseudomonas syringae pv. syringae B728a, S8: Pseudomonas stutzeri strain 28a24, S10: Pseudomonas fluorescens strain LMG 2189

Means sharing the same letters are statistically non-significant with the Duncan's new multiple range test at $\mathrm{p}<0.05$

These findings are similar to those of Hussain et al. (2006, 2013) and McComb et al. (2012). It is known that the reduction in plant growth by lead

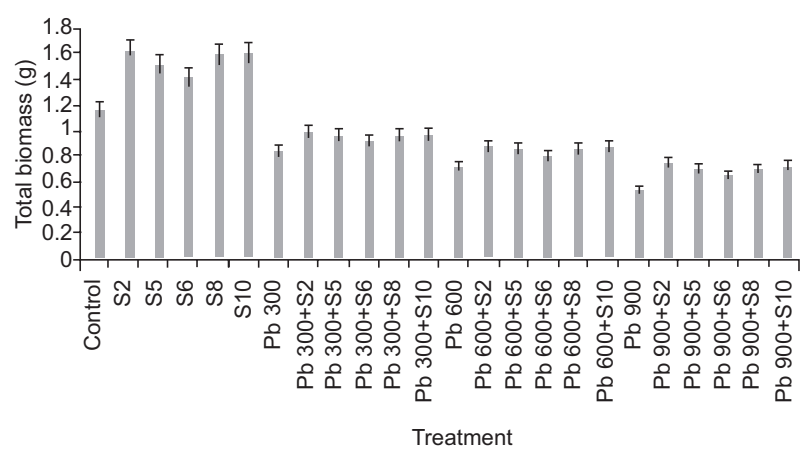

Fig. 1. Effect of lead tolerant plant growth promoting rhizobacteria on total biomass of sunflower plants exposed to lead contamination might be due to its interference with the uptake of nutrients, respiration, photosynthetic rate and cell membrane permeability (Sharma and Dubey 2005). Lead can also disrupt the activity of enzymes in various metabolic pathways such as those involved in the photosynthetic Calvin cycle, and the metabolism of nitrogen and sugar (Verma and Dubey 2003).

Data regarding a reduction in physiological attributes (photosynthetic and transpiration rate, substomatal CO2) by lead contamination might be due to lead, which prevents the incorporation of $\mathrm{Fe}$ in the phyto porphyrin ring of the chlorophyll molecule, causing a reduction in chlorophyll synthesis/content (Shakya et al. 2008). Lead decreases the synthesis of chlorophyll either by reducing the chlorophyllase activity or by decreasing the uptake of essential elements like Mg and Fe by plants (Sharma and Dubey 
2005). Lead also causes degradation of the chlorophyll molecule (Dogan and Colak 2009).

Inoculation with lead tolerant bacteria in lead contamination reversed the toxic effect of lead and improved the growth and physiology of sunflower as compared to uninoculated plant grown in lead stress. This improvement with lead tolerant PGPR might be due to phosphate solubilization (Yasmin and Bano 2011, Peña and Reyes 2007), siderophore production (Glick et al. 1999, Meyer 2000), phytohormones production (Asghar et al. 2004, Humphry et al. 2007), and induced systemic resistance in plants against phytotoxicity of metals (Mishra et al. 2006), which may result in plant growth promotion through the improvement of total biomass production. PGPR may also improve the uptake and availability of nutrients by recycling of organic wastes (Asghar et al. 2006). Kumar et al (2009) reported that PGPR Enterobacter aerogenes and Rahnella aquatilis decreased $\mathrm{Ni}$ and $\mathrm{Cr}$ toxicity in Brassica juncea (Indian mustard) and improved plant growth under pot culture experiments.

Improvement of physiological parameters in plants exposed to lead contamination by inoculation with lead tolerant PGPR might be due to the promotion of $\mathrm{Fe}$ uptake by these bacteria in plants, which could have enhanced the chlorophyll content (Burd et al. 2000) and improved the leaf area, which could ultimately improve the photosynthetic rate and other physiological attributes of plants (Glick et al. 1999).

Our research showed that inoculation with lead tolerant bacteria improved the lead content in roots and shoots of sunflower as compared to plants grown in stress without inoculation. These results are similar to the work of Braud et al. (2009), Ma et al. (2011), and Kamran et al. (2015). Data regarding improvement in lead concentration in roots and shoots by inoculation of lead tolerant PGPR might be due to the capability of lead tolerant bacteria to reduce the $\mathrm{pH}$ of soil, which may facilitate metals uptake by converting these elements into a soluble and available form (Abou-Shanab et al. 2006). Bacteria could have produced organic acids, degrading enzymes, iron chelators and siderophores, thus reducing the toxic effect of metals on plants and increasing the uptake of heavy metals (Yousaf et al. 2010). By changing the solubility and availability of pollutants and the production of organic acids, chelates, and redox enhance, plant growth promoting rhizobacteria ehance the uptake of heavy metals in plants, which might also be due to the rhizospheric microbial population in inoculated treatments that mobilize metals and enhance the uptake in plants. For this reason, in the inoculated treatment there is a low amount of lead in sand after harvesting, as compared to lead in contaminated treatments without inoculation. The study of Krishna et al (2012) also suggested that heavy metal levels can be minimized by using bacteria with the ability to produce plant growth promoting trends. Soil microbes associated with plant roots are also helpful in the phytoextraction of heavy metals through the degradation of pollutants (Liao et al. 2006).

This research showed that the evaluation of lead tolerant PGPR on the basis of their plant growth promotion activities, as well as their physiology and phytoremediation potential, is a viable approach to improve plant growth and physiology to remediate heavy metal contamination. Plant growth, physiology and phytoremediation potential can be improved by the synergistic use of plants and microbes.

\section{CONCLUSION}

It might be concluded from this study that lead contamination adversely affected the plant growth and physiology of sunflower. However, the application of lead tolerant PGPR reversed the toxic effect of lead on plant growth and physiology. The study showed that Pseudomonas gessardii strain BLP141, Pseudomonas fluorescens A506, and Pseudomonas fluorescens strain LMG 2189 have a phytoremediation potential, as well as the ability to induce stress tolerance in plants growing in lead stress, and to improve the growth and physiology (photosynthetic rate, transpiration rate and substomatal $\mathrm{CO}_{2}$ ), in plants under various levels of lead contamination.

\section{REFERENCES}

Abou-Shanab R., Angle J. and Chaney R. (2006). Bacterial inoculants affecting nickel uptake by Alyssum murale from low, moderate and high Ni soils. Soil Biol. Biochem. 38 (9), 2882-2889.

DOI: $10.1016 /$ j.soilbio.2006.04.045

Asghar H.N., Zahir Z.A. and Arshad M. (2004). Screening rhizobacteria for improving the growth, yield and oil content of canola (Brassica napus L.). Aust. J. Agric. Res. 55, 187-194. DOI: 10.1071/AJAR03112

Asghar H.N., Ishaq M., Zahir Z.A., Khalid M. and Arshad M. (2006). Response of radish to integrated use of nitrogen fertilizer and recycled organic waste. Pak. J. Bot. 38 (3), 691-700 
Belimov A., Safronova V., Sergeyeva T., Egorova T., Matveyeva. V., Tsyganov V., Borisov A., Tikhonovich I., Kluge C., Preisfeld A., Dietz K. and Stepanok V. (2001). Characterization of plant growth promoting rhizobacteria isolated from polluted soils and containing 1-aminocyclopropane-1-carboxylate deaminase. Can. J. Microbiol. 47 (7), 642-52.

DOI: $10.1139 /$ cjm 2012-0570

Bingham F.T., Pereyea F.J. and Jarrell W.M. (1986). Metal toxicity to agricultural crops. Metal Ions Biol. Syst. 20, 119-156.

Bottini R., Cassán F. and Piccoli P. (2004). Gibberellin production by bacteria and its involvement in plant growth promotion and yield increase. Appl. Microbiol. Biotechnol. 65, 497-503.

DOI: $10.1007 / \mathrm{s} 00253-004-1696-1$

Braud A., Jézéquel K., Bazot S. and Lebeau T. (2009). Enhanced phytoextraction of an agricultural Cr-, Hgand $\mathrm{Pb}$-contaminated soil by bioaugmentation with siderophore producing bacteria. Chemosphere 74, 280-286. DOI: 10.1016/j.chemosphere. 2008.09.013

Burd G.I., Dixon D.G. and Glick B.R. (2000). Plant growth promoting bacteria that decrease heavy metal toxicity in plants. Can. J. Microbiol. 46, 237-245.

DOI: $10.1139 /$ w99-143

Chen L., Shenglian L., Xiaojie L., Jueliang C. and Chengbin L. (2014). Interaction of Cd-hyperaccumulator Solanum nigrum L. and functional endophyte Pseudomonas sp. Lk9 on soil heavy metals uptake. Soil Biol. Biochem. 68, 300-308. DOI: 10.1016/j.soilbio.2013.10.021

Cheng S. (2003). Heavy metals in plants and phytoremediation. Environ. Sci. Pollut. Res. 10, 5-10.

DOI: $10.1065 /$ espr2002.11.141.3

Chibuike G.U. and Obiora S.C. (2014). Heavy metal polluted soils: Effect on plants and bioremediation methods. Appl. Environ. Soil. Sci. 2014, 1-12. DOI: $10.1155 / 2014 / 752708$

Dermont G., Bergeron M., Richer-Lafleche M. and Mercier G. (2010). Remediation of metal-contaminated urban soil using flotation technique. Sci. Total Environ. 408 (5), 1199-1211. DOI: 10.1016/j.scitotenv.2009.11.036

Dogan M. and Colak U. (2009). Effect of lead applied to Triticum aestivum L. cv. to sunbey on some physiological characteristics. Ekoloji. 19 (73), 98-104.

Egamberdiyeva D. (2007). The effect of plant growth promoting bacteria on growth and nutrient uptake of maize in two different soils. Appl. Soil Ecol. 36, 184-189.

DOI: 10.1016/j.apsoil.2007.02.005

Faryal R., Sultan A., Tahir F., Ahmed S. and Hameed A. (2007). Biosorption of lead by indigenous fungal strains. Pak. J. Bot. 39, 615-622.

Glick B.R., Patten C.L., Holguin G. and Penrose D.M. (1999). Biochemical and genetic mechanisms used by plant growth promoting bacteria. Imperial College Press, London, 270 pp. DOI: 10.1142/p130

Glick B.R., Penrose D. and Li J. (1998). A model for the lowering of plant ethylene concentrations by plant growth-promoting bacteria. J. Theor. Biol. 190, 63-68. DOI: 10.1006 / jtbi.1997.0532

Grčman H., Velikonja-Bolta Š., Vodnik D., Kos B. and Leštan D. (2001). EDTA enhanced heavy metal phytoextraction: metal accumulation leaching and toxicity. Plant Soil 235, 105-114. DOI: 10.1023/A:101185730

Hadi F. and Bano A. (2009). Utilization of Parthenium hysterophorus for the remediation of lead-contaminated soil. Weed Biol. Manag. 9, 307-314.

DOI: 10.1111/j.1445-6664.2009.00355.x

Hadi F., Bano A. and Fuller M.P. (2010). The improved phytoextraction of lead $(\mathrm{Pb})$ and the growth of maize (Zea mays L.): The role of plant growth regulators (GA $\mathrm{G}_{3}$ and IAA) and EDTA alone and in combinations. Chemosphere 80, 457-462.

DOI: $10.1016 /$ j.chemosphere.2010.04.020

Hoagland D.R. and Arnon D. (1950). The water culture methods for growing plants without soil. Calif. Agric. Exp. Sta. Cir. 347, 1-39.

Humphry D.R., Andrews M., Santos S.R., James E.K., Vinogradova L.V., Perin L., Reis V.M. and Cummings S.P. (2007). Phylogenetic assignment and mechanism of action of a crop growth promoting Rhizobium radiobacter strain used as a biofertilizer on graminaceous crops in Russia. A. van Leeuw. J. Microb. 91, 105-113. DOI: $10.1007 / \mathrm{s} 10482-006-9100-\mathrm{z}$

Hussain M., Sajid M., Ahmad A. and Kausar A. (2006). Effect of lead and chromium on growth, photosynthetic pigments and yield components in mash bean [Vigna mungo (L.) Hepper]. Pak. J. Bot. 38, 1389-1396.

Hussain A., Abbas N., Arshad F., Akram M., Khan Z.I., Ahmad K. and Mirzaei F. (2013). Effects of diverse doses of lead $(\mathrm{Pb})$ on different growth attributes of Zea mays L. Agric. Sci. 4(5), 262-265.

DOI: $10.4236 /$ as.2013.45037

Jadia C.D. and Fulekar M.H. (2009). Phytoremediation of heavy metals: Recent techniques. Afr. J. Biotechnol. 8, 921-928. DOI: 0.5897/AJB2009.000-9152

Jing Y., Zhen-li H. and Xiao Y. (2007). Role of soil rhizobacteria in phytoremediation of heavy metal contaminated soils. J. Zhejiang University-Science 8 (3), 192-207. DOI: 10.1631/jzus.2007.B0192

Kamran M.A., Syed J.H., Musstjab S.A., Eqani A.S., Munis M.F.H. and Javed C.H. (2015) Effect of plant growth-promoting rhizobacteria inoculation on cadmium (Cd) uptake by Eruca sativa. Environ. Sci. Pollut. Res. 22, 9275-9283. DOI: 10.1007/s11356-015-4074-x Khan M.S., Almas Z., Ahmad W.P. and Mohammad O. (2009). Role of plant growth promoting rhizobacteria 
in the remediation of metal contaminated soils. Environ. Chem. Lett. 7, 1-19.

DOI: $10.1007 / \mathrm{s} 10311-008-0155-0$

Koo S.-Y. and Cho K.-S. (2009). Isolation and characterization of a plant growth-promoting rhizobacterium Serratia sp. SY5. J. Microbiol. Biotechnol. 19 (11), 1431-1438. DOI: 10.4014/jmb.0904.04014

Krishna M.P., Varghese R., Babu A.V. and Hatha A.A.M. (2012). Bioaccumulation of cadmium by Pseudomonas sp. isolated from metal polluted industrial region. Environ. Res. Eng. Manag. 61(3), 58-64. DOI: $10.5755 / \mathrm{J} 01$. erem.61.3.1268

Kumar K.V., Srivastava S., Singh N. and Behl H.M. (2009). Role of metal resistant plant growth promoting bacteria in ameliorating fly ash to the growth of Brassica juncea. J. Hazard. Mater. 170, 51-57.

DOI: 10.1016/j.jhazmat.2009.04.132

Liao Y.C., Chien S.W., Wang M.C., Shen Y., Hung P.L. and Biswanath D. (2006). Effect of transpiration on $\mathrm{Pb}$ uptake by lettuce and on water soluble low molecular weight organic acids in rhizosphere. Chemosphere 65(2), 343-351.

DOI: 10.1016/j.chemosphere.2006.02.010

Ma Y., Prasad M.N.V., Rajkumar M. and Freitas H. (2011). Plant growth promoting rhizobacteria and endophytes accelerate phytoremediation of metalliferous soils. Biotechnol. Adv. 29, 248-258.

DOI: $10.1016 /$ jbiotechadv.2010.12.001

Mamaril J.C., Paner E.T. and Alpante B.M. (1997). Biosorption and desorption studies of chromium (III) by free and immobilized Rhizobium (BJVr 12) cell biomass. Biodegrad. 8, 275-285. DOI: $10.1023 / A: 1008213712910$

Mangkoedihardjo S. and Surahmaida. (2008). Jatropha curcas L. for phytoremediation of lead and cadmium polluted soil. World Appl. Sci. J. 4, 519-522.

McComb J., Hentz S., Miller G.S. and Begonia M. (2012). Effects of lead on plant growth, lead accumulation and phytochelatin contents of hydroponically-grown Sesbania exaltata. World Environ. 2 (3), 38-43. DOI: $10.5923 /$ j.env.20120203.04

Meyer J.M. (2000). Pyoverdines: Pigments, siderophores and potential taxonomic markers of fluorescent Pseudomonas sp. Arch. Microbiol. 174, 135-142. DOI: $10.1007 / \mathrm{s} 002030000188$

Mishra R.P.N., Singh R.K., Jaiswal H.K., Kumar V. and Maurya S. (2006). Rhizobium-mediated induction of phenolics and plant growth promotion in rice (Oryza sativa L.). Curr. Microbiol. 52, 383-389. DOI: 10.1007/ s00284-005-0296-3

Mourato M.P., Moreira I.N., Leitão I., Pinto F.R., Sales J.R. and Martins L.L. (2015). Effect of heavy metals in plants of the genus Brassica. Int. J. Molecul. Sci. 16 (8), 17975-17998. DOI: 10.3390 ijms 160817975

Peña H.B. and Reyes I. (2007). Nitrogen fixing bacteria and phosphate solubilizers isolated in lettuce (Lactuca sativa L.) and evaluated as plant growth promoters. Interciencia 32, 560-565.

Sewalem N., Soad E. and Fatma S. (2014). Phytoremediation of lead and cadmium contaminated soils using sunflower plant. J. Stress Physiol. Biochem. 10 (1), 122-134.

Shakya K., Chettri M. and Sawidis T. (2008). Impact of heavy metals (copper, zinc, and lead) on the chlorophyll content of some mosses. Arc. Environ Contam. Toxicol. 54, 3. DOI: 10.1007/s00244-007-9060-y

Sharma P. and Dubey R.S. (2005). Lead toxicity in plants. Braz. J. Plant Physiol. 17 (1), 35-52. DOI: $10.1590 / \mathrm{S} 1677-04202005000100004$

Steel R.G.D. and Torrie J.H. (1984). Principles and procedures of statistics. McGraw-Hill, New York, USA, $666 \mathrm{pp}$.

Terry N. and Bañuelos G. (2000). Phytoremediation of contaminated soil and water. Lewis Publishers, New York, USA, 389 pp.

Tuzen M. (2003). Determination of heavy metals in soil, mushroom and plant samples by atomic absorption spectrophotometry. Microchem. J. 74, 289-297. DOI: $10.1016 / \mathrm{S} 0026-265 \mathrm{X}(03) 00035-3$

Verma S. and Dubey R.S. (2003). Lead toxicity induces lipid peroxidation and alters the activities of antioxidant enzymes in growing rice plants. Plant Sci. 164, 645-655. DOI:10.1016/S0168-9452(03)00022-0

Yasmin H. and Bano A. (2011). Isolation and characterization of phosphate solubilizing bacteria from rhizosphere soil of weeds of Khewra salt range and Attock. Pak. J. Bot. 43 (3), 1663-1668.

Yousaf S., Andri V., Reichenauer T.G., Smalla K. and Sessitsch A. (2010). Phylogenetic and functional diversity of alkane degrading bacteria associated with Italian ryegrass (Lolium multiflorum) and birds foot trefoil Lotus corniculatus in a petroleum oil-contaminated environment. J. Hazard. Mater. 184 (1-3), 523-532. DOI: $10.1016 / j$.jhazmat.2010.08.067. 